\title{
Erratum to: Optimization of adipose tissue- derived mesenchymal stem cells by rapamycin in a murine model of acute graft-versus-host disease
}

Kyoung-Woon Kim ${ }^{1 \dagger}$, Su-Jin Moon ${ }^{2+}$, Min-Jung Park ${ }^{3}$, Bo-Mi Kim', Eun-Kyung Kim³ ${ }^{3}$ Sung-Hee Lee ${ }^{3}$, Eun-Jung Lee ${ }^{3}$, Byung-Ha Chung ${ }^{1,4}$, Chul-Woo Yang ${ }^{1,4,5^{*}}$ and Mi-La Cho ${ }^{1,3^{*}}$

After publication of this article [1] in the journal Stem Cell Research and Therapy, it was brought to our attention that the acknowledgement section was not complete. The correct acknowledgement section should read:

This research was supported by the Bio \& Medical Technology Development Program of the National Research Foundation (NRF) funded by the Korean government (MEST) (No. 2012M3A9C6049783) and by a grant of the Korean Health Technology R\&D Project, Ministry for Health \& Welfare, Republic of Korea.(HI14C3417). The authors declare that they have no competing interests.

\footnotetext{
Author details

${ }^{1}$ Convergent Research Consortium for Immunologic disease, Transplant Research Center, The Catholic University of Korea, Seoul, South Korea. ${ }^{2}$ Division of Rheumatology, Department of Internal Medicine, College of Medicine, The Catholic University of Korea, Seoul, South Korea. ${ }^{3}$ The Rheumatism Research Center, The Catholic University of Korea, Seoul, South Korea. ${ }^{4}$ Division of Nephrology, Department of Internal Medicine, College of Medicine, The Catholic University of Korea, Seoul, South Korea. ${ }^{5}$ Department of Internal Medicine, Seoul St. Mary's Hospital, 505 Banpo-Dong, Seocho-Ku 137-040, Seoul, Korea.
}

Received: 14 April 2016 Revised: 27 April 2016

Accepted: 4 May 2016 Published online: 31 May 2016

\section{Reference}

1. Kim et al. Optimization of adipose tissue-derived mesenchymal stem cells by rapamycin in a murine model of acute graft-versus-host disease. Stem Cell Research \& Therapy. 2015; 6:202.

\footnotetext{
* Correspondence: yangch@catholic.ac.kr; iammila@catholic.ac.kr †Equal contributors

${ }^{1}$ Convergent Research Consortium for Immunologic disease, Transplant Research Center, The Catholic University of Korea, Seoul, South Korea
}

\footnotetext{
Submit your next manuscript to BioMed Central and we will help you at every step:

- We accept pre-submission inquiries

- Our selector tool helps you to find the most relevant journal

- We provide round the clock customer support

- Convenient online submission

- Thorough peer review

- Inclusion in PubMed and all major indexing services

- Maximum visibility for your research
}

Submit your manuscript at www.biomedcentral.com/submit 